\section{Surgical techniques: past, present and future}

\author{
Karim Qayumi \\ Centre of Excellence for Simulation \\ Education and Innovation, Department \\ of Surgery, Division of Cardiovascular \\ and Thoracic Surgery, University \\ of British Columbia, Vancouver, British \\ Columbia, Canada
}

\section{Abstract}

The aim of this paper is to provide an analytical survey of the information available on the development of past and present surgical techniques, and to make projections for the future. For the purposes of this paper, the Past starts in the Neolithic period and ends in the 1800s. In this context, I have divided the Past into Prehistoric, Ancient and Middle Ages, and this period ends in the second half of the $19^{\text {th }}$ century when the major obstacles to the further development of surgery, such as overcoming pain and infection, were removed. We will discuss the development of surgical techniques, and the obstacles and opportunities prevalent in these periods. In the context of this paper, the Present begins in 1867, when Louis Pasteur discovered microorganisms, and ends in the present day. There have been many important changes in the development of surgical techniques during this period, such as the transfer of surgery from the unsterile operating room to the modern hospital operating theater, the development of advanced and specialized surgical practices, such as transplants and laparoscopy, and minimally invasive surgical methods, robotic and Natural Orifice Transluminal Endoscopic Surgery. It is very difficult to foresee how surgical techniques will develop in the Future because of the unpredictable nature of technological progress. Therefore, in this paper, the forecast for the Future is limited to the next 50100 years and is a realistic calculation based on already existing technologies. In this context, the Future is divided into the development of surgical techniques that will develop in the near and distant future. It is anticipated that this overview will shed light on the historical perspective of surgical techniques and stimulate interest in their further development.

\section{Introduction}

\section{A definition of surgical technique}

In my quest for information about surgical techniques, I was surprised to learn that there is no clear definition. Many terms such as surgery, surgical procedure and surgical skills are used interchangeably, and are used to loosely describe surgical technique. Consequently, I believe that it is important to clarify just what is meant by surgical technique and to provide a specific definition.

On the World Wide Web, ${ }^{1,2}$ surgical technique is defined as surgery. The word surgery or chirurgia is derived from the Greek word chir which means hand and chirurgia meaning hand work. Chirugia is an ancient medical practice that uses hands, manual instruments and techniques to investigate, treat and improve bodily function or appearance, or to satisfy religious cultural rules and regulations. It is my opinion that surgery is not synonymous to surgical techniques because by definition surgery is a medical speciality that uses operative manual and instrumental techniques on the patient to investigate and/or treat a pathological condition. Thus, the word surgery is a much more general term than surgical technique.

The term surgical procedure is also used to loosely describe and define surgical techniques. By definition, ${ }^{3,4}$ the term procedure is a particular course of action intended to achieve a particular result. In more specific terms, a procedure is a specified series of actions, or operations that must always be executed in the same way in order to replicate the same result under the same circumstances every time. In some cases, surgical procedure is used synonymously with the word operation. However, in this case, operation is defined ${ }^{5}$ as a medical procedure involving an incision with instruments performed to repair damage or to cure disease in a living body. According to these definitions, it is obvious that a surgical procedure has a much broader meaning compared to the concept of a surgical technique. In some scholarly papers, surgical technique is also confused with surgical skill. The word skill is defined as the ability to perform certain procedures $s^{6,7}$ and the word technique is defined as a particular method or art applied to the same particular task to improve proficiency. ${ }^{8,9}$

Consequently, surgical technique may be defined as a specific method or art applied in the performance of a specific surgical task in a surgical procedure. For example, any surgery will have a pre-operative procedure, an operating procedure and a post-operative procedure and the operating procedure will consist of many tasks. The surgical techniques are the art or method by which these specific tasks are performed.

With this definition in mind, surgical techniques can be divided into basic and advanced specialized surgical techniques. The basic surgical techniques include those methods and/or arts that are used for the performance of basic tasks that are common among most surgical procedures such as knot-tying, suturing,
Correspondence: Karim Qayumi, Centre of Excellence for Simulation Education and Innovation, Department of Surgery, University of British Columbia 3602 - 910 West 10th Avenue, Vancouver, B.C. V5Z 4E3 Canada.

Tel. +1.604.875.4499 - Fax: +1.604.875.5832

E-mail: qayumi@mail.ubc.ca

Key words: surgical techniques, history.

Received for publication: 31 0ctober 2011.

Revision received: 22 March 2012.

Accepted for publication: 2 April 2012.

This work is licensed under a Creative Commons Attribution NonCommercial 3.0 License (CC BYNC 3.0).

(C) Copyright K. Qayumi, 2012

Licensee PAGEPress, Italy

Surgical Techniques Development 2012; 2:e9 doi:10.4081/std.2012.e9

clamping, dissection, etc. Advanced surgical techniques on the other hand, include methods employed in the performance of specific tasks used to realize specialized surgical procedures, such as plastic, cardiac, vascular and other surgeries. Thus, each surgical procedure consists of basic and advanced surgical techniques that can be taught to improve the proficiency of the learner.

With a clearer understanding of the meaning of surgical technique, we should analyze the literature on the origin of surgical techniques, the status of surgical techniques today, and what the future holds for the art of surgical performance. Today's surgical techniques are a result of centuries of human development, experiential learning, and empirical and scientific knowledge. This manuscript intends to provide an analytical review of the information available on past and present surgical techniques and to make projections for the future.

\section{The past}

For the purposes of this paper, the Past includes the Neolithic period and concludes in the second half of the $19^{\text {th }}$ century, a critical point in time when major obstacles to the development of surgical techniques (such as issues of pain management and infection) were overcome. For the purpose of clarity, ease of understanding and analysis, the history of surgical technique may be divided into the following subheadings: i. prehistoric; ii. ancient; iii. middle ages.

\section{Surgical techniques in prehistoric times}

Archaeological evidence suggests that surgical techniques were practised before ancient civilization and date as far back as the Stone and Bronze Ages. It is known that primitive 
human beings performed complex surgical procedures such as trepanation to treat head injuries, or perhaps to treat problems other than those caused by injury. Proof that such surgical techniques existed was provided when a 9000-year old skull was unearthed with a man-made hole drilled or scripted into it that exposed dura mater. ${ }^{10-12}$ Furthermore, cave paintings from the Neolithic period $(25,000$ 30,000 years ago) serve as a historical record that such surgical procedures were not only performed, but that some of these patients survived. ${ }^{13,14}$ The remains of the skull together with the cave paintings offer sufficient evidence that complex surgical techniques were practised often enough for surgical skills to be mastered and maintained.

Archaeological excavations around the Indus River in Pakistan have revealed human remains dating back 9000 years to the early Harappan period. These remains show evidence that a tooth drill had been employed. ${ }^{14,15}$ A similar type of tooth drilling practice was found in human remains from ancient Egypt from around $2600 \mathrm{BC}$; there was evidence that drilling had been performed on the mandible just below the root of the first molar, and perhaps used to drain an abscessed tooth. ${ }^{16,17}$ Archeological findings from these bones are the only evidence we have to suggest that complex surgical techniques were practiced in prehistoric times. However, one cannot necessarily come to the conclusion that surgeons in the prehistoric era were only able to perform operations on skull, teeth or other bones. Neither can it be taken for granted that they did not master any other surgical techniques on soft tissue in other areas of the body. The lack of descriptive literature and archeological evidence on surgery to soft tissue means that there is no evidence to describe the full spectrum of surgical techniques mastered in prehistoric times. However, the logical conclusion is very simply made from what we do know: a surgeon who was able to perform trepanation of the skull and drilling of the tooth or mandible could also very well be capable of performing other surgical procedures such as interventions involving soft tissue.

\section{Surgical techniques in ancient times}

Descriptions of surgical techniques in ancient times relate to specific ancient civilizations. Therefore, it is important to discuss surgical techniques in the context of each distinct civilization.

\section{Surgical techniques in ancient Egyptian civilization}

As mentioned previously, the initial development of surgical techniques in ancient Egyptian civilization could date back to prehistoric times. It is the ancient Egyptians who are credited with the first documentation of surgi- cal procedures over 3500 years ago. ${ }^{16}$ In ancient Egypt, priests were also trained in medical treatment and performed surgical procedures alongside physicians. Medical records were organized in a manner very similar to our records today. All patients' charts and files were documented on papyrus. Herodotus studied and analyzed the Egyptian surgical system and wrote, ...the practice of medicine is very specialized among them, each physician treats just one disease. The country is full of physicians, and some treat eyes, teeth, and some problems belong to the abdomen and others internal diseases... ${ }^{16,17}$ The ancient Egyptians are also credited with outstanding work in the development of surgical techniques, such as dissection and anatomy, as well as in the development of a variety of surgical instruments. ${ }^{18}$

\section{Mesopotamia (Babylonian civilization)}

In contrast to the Egyptians, Babylonian doctors were considered to be witch doctors who used magic and religious ceremony in their patient care, as well as scientific methods..$^{19}$ In this civilization, surgery was developed to a particular level of perfection due to a law known as the code of Hammurabi (1700 BC). ${ }^{20}$ This code called for a surgeon's hands to be cut off if the operation was performed incorrectly, and surgeons were killed if the patient died as a result of the surgical procedure. ${ }^{20}$ This law was not, however, applied to the peasants and was only enforced for upper class patients. A surgeon who carried out an unsuccessful operation on a peasant would simply have to pay a fine. One could say then that Babylonian civilization legally permitted surgeons to experiment on peasants in order to perfect surgical techniques. They were allowed to practice on upper-class individuals only when they were one hundred percent confident of their skills. Since the stakes for surgeons were so high if upper class patients died while undergoing surgery, it is reasonable to conclude that surgical techniques were highly developed in the Babylonian civilization and only an excellent surgeon with outstanding surgical techniques could survive.

\section{Indian civilization}

Ancient Indians were well known for their advancement in surgical techniques, tools and technologies, particularly with regard to general, plastic and Ear, Nose and Throat surgery. ${ }^{21}$ I would suggest that the reason they were so developed in these areas was due to a northern Indian religious belief and fable that dates back to $1000-2000$ BC. In this fable, Rama, Prince of India, was confronted by the demon Shuurpanakh who wanted to make love to the prince. Of course, Prince Rama refused the demon and ordered his brother to cut off her nose, spit on her face and have the demon live with shame forever. This story was a source of guidance and inspiration for ancient Indians who sanctioned cutting the nose off a person who acted shamefully; it was applied particularly to female adulterers. This may have conditioned the environment in which surgeons in ancient India perfected plastic surgery techniques. Among the physicians who became famous for working out the principles of surgical techniques and plastic surgery, we know of Sushrutha Benares (600 BC), who is called the father of surgery in Indian traditional medicine. ${ }^{22}$ In his important multi-volume book entitled Sushrutha Samhita, Sushrutha documented all his surgical procedures, techniques and instruments, as well as his experience with patients. ${ }^{23}$ The other important contribution Sushrutha made to medicine was the introduction of simulation in a laboratory environment in order to demonstrate particular surgical techniques or procedures using models, fruit and other objects. In his book, written in Sanskrit, he describes over 120 surgical instruments and over 300 surgical procedures and operating techniques. He classified human surgery procedures into eight categories, and described surgical techniques for many of these procedures such as plastic and cataract surgery, caesarean section and others. ${ }^{23}$

\section{Chinese civilization}

Surgical techniques were also developed by the Chinese. However, the main achievement of Chinese civilization in the field of surgery is the development of anesthesia. ${ }^{23,24}$ The Chinese were the first to use and document the use of alcohol in combination with some type of canapé to induce anesthesia during surgery. This certainly provided a suitable environment in which surgical techniques could flourish. The most famous surgeon in ancient China was Tuo Hua who lived during the Han Dynasty (190 BC). Tuo Hua was the first to use anesthesia in surgery, and he monitored the human pulse for the diagnosis and assessment of patient health. ${ }^{25} \mathrm{He}$ also developed surgical techniques for a variety of surgical procedures including skull surgery. Unfortunately, no documentation has come down to us to illustrate how far he developed his surgical techniques. However, the story goes that Cao Cao, the Emperor of China during the Wei Dynasty, suffered from headaches and that Tuo Hua promised to cure him by opening his skull. Certain physicians (Ji-Ping) had previously attempted to assassinate Cao Cao and he thought that Tuo Hua also wanted to kill him. Cao Cao accused him of attempted murder and Tuo Hua was imprisoned. While in prison, he wrote a book on surgical techniques entitled Qing Nung Shu (Medical Practice Book) and giving it to the jailer he said this can save lives. The jailer did not accept the book and then, upon the request of Tuo Hua, the book was burned. ${ }^{25}$ 


\section{Greek civilization}

Surgical techniques developed in ancient Greece were mainly related to war injuries. Building on the knowledge and experience from other civilizations, the ancient Greeks performed and perfected surgical techniques such as wound closure, amputations, the application of tourniquets, vascular ligature for homeostasis and others. ${ }^{26}$ In addition to the further development of surgical techniques, the Greeks are well known for their surgical education. ${ }^{27}$ The semi-formal schools of Aesculapius trained many physicians, including Hippocrates who is known in the Western world as the father of modern medicine. ${ }^{28}$ More importantly, the ancient Greeks standardized teaching in health disciplines such as medicine and surgery. Aesculapius was the son of Apollo and in Greek mythology he was the god of health. The ancient Greeks also further developed the use of plants for treatment of wounds in the pre- and post-operative stages of patient care, as well as during surgery. ${ }^{29}$

\section{Roman civilization}

Much like the Greek civilization, many of the surgical techniques developed in the Roman Empire were profoundly shaped by war. ${ }^{28}$ The Romans are renowned for the development of on-site operating theaters in the field, as well as for ambulance-like carriages that transported wounded soldiers from the battlefield to the operating theater. ${ }^{28}$ The operating theaters consisted of tents that were located behind the line of defense. The strength of the organizational structure that the Romans employed to provide healthcare on the battlefield was not improved upon until the time of Napoleon. ${ }^{27}$ Field surgery was so developed that the field surgeons were given the special title of Medicus Vulnerarius (wound doctor) which differentiated them from regular doctors who only took care of the civilian population. ${ }^{29}$ The most famous Medicus Vulnerarius was Pedanios Dioscorides (65 AD) who wrote a book on the use of medical herbs that became the standard reference treatise for the next 1500 years. Galen (Galenus) was probably the greatest physician/surgeon and philosopher in the Roman Empire and the legacy of his surgical skills was not surpassed for many years. ${ }^{30}$ Michael Angelo, a famous Roman philosopher and artist, once said ... it is better to be wrong following Galen and Ibin Sina than to be right following others. ${ }^{31}$

\section{Surgical techniques in Islamic civilizations}

Islamic civilizations rose and flourished when Europe entered the Dark Ages and the Western world no longer had easy access to the knowledge created by the ancient civilizations. ${ }^{32}$ During this period, when extreme reli- gious ideologies prohibited the advancement of knowledge, and scientific methods were considered a sin, the young and prosperous Islamic civilization served not only as a host and repository for prior knowledge, but also developed new knowledge on the basis of earlier work that had been described by other ancient civilizations. As a result, the Islamic civilization served as a bridge that brought scientific knowledge from the past into the future. The city of Balkh, in the ancient province of Khorasan (known today as northern Afghanistan), stood at the centre of the Silk Road, at the crossroads of economic, cultural and political highways for a number of civilizations ${ }^{33}$ and an area of cultural integration between East and West. Balkh provided a cultural reality that gave birth to many famous poets and philosophers such as Rumi, pharmacologists such as Al-Beroony, physicians such as Ibin Sina, and others. ${ }^{31}$ In the world of medicine and surgery, Ibn Sina (known in the West as Avicenna) is considered one of the greatest physicians of all time. Avicenna was not only a physician and surgeon, he was also a great philosopher, poet, astronomer, musician and mathematician. He was a true Renaissance man and was a prolific writer. Over two hundred and forty-six of his manuscripts have survived down to us. The most famous of his publications, Al-Shefa, is the first known medical encyclopedia that classified medical knowledge and is made up of twenty volumes. ${ }^{34}$ In the Western medical world, Ibn Sina is renowned for his book entitled Al-Qanun fe-Teb (The Canon of Medicine).$^{35}$ This book served as the seminal textbook for medical students across the globe, particularly in Europe, from the $12^{\text {th }}$ until the $19^{\text {th }}$ century. ${ }^{31}$ The book was so popular in Europe that when the printing press was invented (around 1440), it was the first book after the Bible to be printed for mass distribution. Ibn Sina's contribution to medicine is not, however, limited to his writings. He developed medical and surgical knowledge in several areas. For instance, he was the first to demonstrate that tuberculosis is infectious, to identify meningitis as an infectious disease, and to propose quarantine as a method to limit the spread of infectious disease. He had a surgical ward where he diagnosed and treated patients, and he devised a variety of new surgical techniques. Although we have no written confirmation, first hand accounts that have been passed on to us orally tell us that Ibn Sina performed a cholecystectomy on a famous pharmacologist of the time, AlBeroony. His place in the history of medicine is so important that the World Health Organization declared an international celebration of the thousandth anniversary of his birth. ${ }^{36}$

Abu Bakr Muhammad Ibn Zakariya Razi
(865- $925 \mathrm{AD}$ ), known in the West as Rhazes or Rasis, is recognized by most medical scholars as second only to Ibn Sina in his scholarly accomplishments. ${ }^{37}$ He wrote over two hundred books. The most well-known of his manuscripts include Kitab Almansur, ${ }^{37}$ a ten-volume book on Greek medicine, and $a l$-Hawi ${ }^{38}$ a medical encyclopedia that served as a reference book of knowledge from Greek, Roman, Chinese, Indian, Babylonian and Arabic civilizations. His revolutionary approach classified substances into vegetables, animals and minerals as opposed to the then universally accepted classifications of bodies, souls and spirits. As far as surgical techniques are concerned, Rasis developed treatment modalities for the removal of kidneys and bladder stones. While he served as the head of Muqtadari Hospital in Bagdad, Rasis carried out research into infectious diseases including surgical infections, small pox, measles and others. He was an expert surgeon who made wide use of opium in surgical procedures. He also emphasized the important roles that food, psychology and psychotherapy play in the treatment of patients undergoing surgery. ${ }^{37,38}$

The third Islamic scholar who made an important contribution to the development of medical knowledge and surgical techniques is Abu al-Qasim Khalaf ibn al-Abbas Al-Zahrawi, known in the West as Albucasis, born in $936 \mathrm{AD}$ in Granada, Spain.$^{39} \mathrm{He}$ was the personal physician to the king of Spain, King Al-Hakam II. He is well known for his outstanding breakthroughs in surgery as well as for documenting and writing texts on surgical procedures that shaped the field of European surgery until the end of the Renaissance. His famous book, Kitab al-Tasrif, is a treatise in thirty volumes is the centerpiece of his many publications..$^{40}$ Interestingly, three volumes of this treatise are devoted to surgical techniques. It contains about two hundred illustrations and describes surgical techniques involving removing kidney stones, eye, ear, nose and throat surgery, cauterization of wounds, tumors, bleeding, and open wound infections. His techniques became standard medical treatments. ${ }^{41}$ Advanced surgical techniques that included division and separation of the temporal artery to relieve headaches, diversion of urine into the rectum, reduction mammoplasty for excessively large breasts and the extraction of cataracts are the most important among the wide range of surgical techniques he developed. ${ }^{41}$

\section{European civilization}

The Medieval period was not a good time for European science and medicine, and this was felt particularly in the development of surgical techniques. ${ }^{39}$ The early Medieval times, also known as the Dark Ages, was a period in history when Western religious authorities were opposed to scientific reasoning. The Church 
considered the treatment of live human bodies and corpses for scientific investigation as a violation and an unforgivable sin. In addition, during that time any knowledge from past civilizations was abandoned, and study and learning were forbidden. Historians disagree as to when the Dark Ages began and when they ended in the Western world. Some believe it concerns the period 350-500 AD, some believe it was 500-700 $\mathrm{AD}$ while still others believe it extended to $900 \mathrm{AD}$. However, one fact is clear, and that is that Islamic and Jewish scholars played an important role in the preservation and reintroduction of Greek and Roman knowledge back into Europe. For example, the Jewish scholar Maimonides had a significant role in translating Arabic texts back into Latin. ${ }^{39}$

The contribution of Andreas Vesalius (1543 $\mathrm{AD})$, a great Italian anatomist, also did much to advance surgical techniques during the Renaissance. ${ }^{32}$ The rise of universities in the West provided an opportunity for Montpellier, Padua and Bologna to become important centers for the advancement of medical and surgical knowledge in Europe. ${ }^{19}$ Guy de Chauliac was one of the most eminent surgeons in the Middle Ages. His famous book, Chirurgia Magna (1363 AD), greatly influenced the teaching of surgical techniques. ${ }^{42}$ In spite of progress in the study of medicine in the burgeoning European universities, surgery was not considered a physician's job due to the powerful censorship that was prevalent during the Dark Ages. Therefore, people who learned surgical techniques also studied other skills such as music, entertainment, magic and hair cutting. This gave birth to the profession of the barber surgeons who traveled around in caravans carrying out surgical operations in towns and villages. In their spare time, they would cut people's hair and perform as entertainers to help them make a living. ${ }^{32}$

Barber surgeons were not popular because the surgical techniques they used were primitive, painful and often created complications to the initial problem. In London, England's King Henry VII signed a decree which united university surgeons in one academic fellowship. ${ }^{43}$ Ambroise Paré, a famous French surgeon was one who benefitted from this merger. He was a barber surgeon before becoming a famous surgeon in the battlefield. ${ }^{28}$ His surgical techniques were so well developed that he was able to amputate a limb in three minutes. ${ }^{29}$ Dominic John Larry (1760-1842 AD) was another famous surgeon in the Napoleonic army who reintroduced the Roman style field hospitals with operating facilities in tents. He organized a system by which the injured soldiers were brought to the tent hospitals for surgery in flying ambulances or horse-drawn carts. He performed two hundred amputations a day. Despite the great industrial advance- ment of the day, surgical knowledge and operating techniques made little progress, mainly because of two important obstacles: pain and surgical infection.

\section{The present}

The work of French scholar Louis Pasteur ${ }^{44}$ marks the beginning of the modern era in surgical techniques. In 1867, he discovered microorganisms and described their role in fermentation. A year later, a British surgeon and scientist, Joseph Lister, described the presence of microorganisms in infected wounds and proved that microbes are, in fact, the ethological sources of infected surgical wounds. He subsequently described a method that could destroy the microbes in wounds and called it antiseptic technique (anti from the Latin prefix against, and sepsis, infection). ${ }^{45}$ Originally, Lister proposed using $3 \%$ carbolic acid as an antiseptic agent to destroy microorganisms in the wound. But this treatment soon became unpopular with surgeons. It was problematic for two reasons: first, antiseptic such as $3 \%$ carbolic acid destroyed the tissue as well as microorganisms in the wound and, secondly, microbes adapted to the carbolic acid.

Twenty years before Lister's discovery of microorganisms, a young Hungarian surgeon and investigator, Ignaz Semnelwise, proposed that one could prevent contamination of wounds simply by washing one's hands and cleaning the operating surface and materials before they came into contact with the wound itself. At the time, Semnelwise's proposed methods were not accepted because they were not backed by scientific evidence. Semnelwise's aseptic ( $a$ - from the Latin prefix without, and sepsis, infection) method only became popular when the widely used carbolic acid failed to satisfy the needs of the surgical community and when Robert Cook introduced sterilization techniques for surgical materials with steam under pressure. $^{46}$ This reintroduction of the aseptic method was instrumental in the advancement of surgical techniques and was documented in March 1867 under the title of Antiseptic Principles for Practice of Surgery. ${ }^{47}$

The second obstacle to the advancement of surgical techniques was pain management. A new approach to this was developed by two American dentists, Horace Wells and William Morton (1815-1878), who rediscovered anesthesia with the use of laughing gas $\left(\mathrm{N}_{2} \mathrm{O}\right) .{ }^{48,49}$ Their discovery led to the rapid development of surgical techniques in the second half of the $19^{\text {th }}$ century. After this, the way in which surgeons performed surgical procedures changed dramatically. In Britain, John Snow pioneered the use of ether and chloroform to provide safe delivery systems of anesthesia to avoid pain during surgery. As a result, surgeons were able to explore different parts of the body, including the brain, chest and abdominal cavity. ${ }^{50}$
The modern period can be identified by the development of surgical techniques that are distinct from all those previously used and define a new way of schieving surgical objectives: i. transfer of surgical techniques from the theater to the hospital operating room; ii. development of advanced, specialized surgical techniques; iii. surgical techniques for transplantation; iv. laparoscopic and minimally invasive surgical techniques; v. robotic surgical techniques; vi. Natural Orifice Transluminal Endoscopic Surgery (NOTES surgical techniques).

In the $19^{\text {th }}$ and the beginning of the $20^{\text {th }}$ century, operations were performed in an operating room that also served as a classroom. Most hospitals at this time had small galleries where students and members of the public could sit and watch like in a lecture hall. The German surgeon, Gustav Neuber proposed the concept of the modern operating room in $1884 .{ }^{51}$ After the introduction of surgical gloves by the American surgeon, William Halsted in $1890,{ }^{52}$ the new concept of the modern operating room was formally accepted. Slowly, with the construction of modern hospitals and more serious consideration of aseptic conducts and the enforcement of aseptic rules, the modern operating room evolved. This is why, in some places, the operating rooms are still called operating theaters.

During this period, open surgical procedures flourished in different parts of the world. The list is endless of all the surgeons who contributed to the development of surgical techniques during this time. However, surgeons like Astley Cooper (1739-1841), Theodor Billrot (1829-1894), Charles McBurney (1845-1913) and William Halsted (1852-1929) were among the major contributors. Open surgical techniques were further developed in the modern hospital environment, particularly after the Second World War. Many outstanding advanced surgical techniques have been developed in all surgical disciplines, such as general surgery, obstetrics and gynecology, ear, nose and throat, orthopedics, pediatrics, neurosurgery, ophthalmology, endocrine, plastics and reconstructive surgery, peripheral vascular, cardiac, thoracic, and others.

Transplantation of solid organs is another breakthrough in the development of modern surgical techniques. Surgical techniques for solid organ transplantation were developed primarily by a Russian experimental surgeon, Vladimir Demikhov (1916-1998), in the second half of the $20^{\text {th }}$ century. ${ }^{53}$ Demikhov started developing surgical techniques for heart, lung and combined heart-lung transplantation which were subsequently used by Drs. Bernard and Jamison in the latter part of the $20^{\text {th }}$ century. Demikhov also successfully performed head transplantation on a dog. He perfected the art of head transplantation so well that the 
transplanted dog lived with two functioning heads and was capable of eating, drinking, barking and biting! Charles Bernard, who performed the first clinical heart transplantation, visited Demikhov's laboratory twice in $\mathbf{1 9 6 0}$ and in 1963. He considered Demikhov to be his mentor. Demikhov wrote a monograph, Experimental Transplantation of Vital Organs, that still serves as a valuable resource for those active in the field of experimental or clinical transplantation. ${ }^{55-57}$

\section{Minimally invasive surgical techniques}

In minimally invasive surgery (MIS), operations are performed through small $(0.5-1.5 \mathrm{~cm})$ incisions and use images displayed on television monitors to magnify the surgical elements in the surgical field. The key elements include two types of laparoscope. The first is a telescopic rod-lens system that is connected to a video camera. The second is a digital laparoscope, where the charge-coupled device is attached to the end of the laparoscope thus eliminating the rod-lens system. This is replaced with a fiber optic cable system that connects the scope to a cold light source which better illuminates the operating field. The idea of the laparoscopic approach for diagnostic treatment originated between 1902-1910.58 However, it was not until 1972 that Dr. HC Clarke invented, published, patented and presented the laparoscopic surgical technique. ${ }^{59}$ Today, the modified laparoscopic surgical technique is used in other surgical disciplines and is recognized as an MIS technique. MIS is routinely used in many areas of surgery such as general, thoracic, cardiac, orthopedic, obstetrics and gynecology, and others.

\section{Robotic surgery}

The terms robotic surgery, computer assisted surgery, and robotic assisted surgery are used to describe various techniques that have been developed to support a variety of surgical procedures. With robotic surgery, rather than directly handling the instruments, the surgeon uses a computer console to manipulate instruments that are attached to multiple robotic arms. The computer translates the surgeon's movements which are then carried out on the patient by the robot. The surgeons and computer console may be located in close proximity to a robot, such as the Da Vinci surgical robot, ${ }^{60}$ or they may conduct remote surgical procedures at a distance from the robot by using the Zeus robotic surgical system. ${ }^{61}$ Both systems are available on the market and were developed in the late 1990s. In September 2010, the Ann Hovan University of Technology announced the development of the Sophie Surgical System, ${ }^{62}$ the first to employ force feedback haptic technology. Robotic surgery opens a new arena for the development of surgical techniques.

\section{NOTES: Natural Orifice Transluminal \\ Endoscopic Surgery}

NOTES is an acronym for Natural Orifice Transluminal Endoscopic Surgery. It is a surgical technique whereby scarless abdominal operations can be performed by an endoscope passed through a natural orifice (mouth, urethra, vagina and anus). The endoscope then crosses an internal incision in the stomach, urinary bladder, colon or vagina, and the surgical procedure is performed in the insufflated abdominal cavity. Although for the moment NOTES surgical techniques are considered to be experimental in most North American surgical communities, ${ }^{63}$ many surgeons in India, Brazil, Australia, Argentina, Italy ${ }^{64}$ and other countries have performed a variety of these surgical procedures for appendectomies and cholecystectomy/colectomies. The American Society for Gastrointestinal Endoscopy and the Society of American Gastrointestinal and Endoscopic Surgeons have worked together since 2006 to develop standards for the practice of NOTES in North America. ${ }^{65}$

\section{The future of surgical techniques}

It is extremely difficult to predict the future of surgical techniques due to the rapid development of science and technology as a whole, and surgical tool and technologies in particular. However, for practical purposes here, the future of surgical techniques may be divided into the near future and the distant but foreseeable future.

\section{Near future}

The near future of surgical techniques will be related to the further development and exploitation of tools and technologies that exist already and may include: i. expansion of MIS and NOTES procedures; ii. future development of surgical robotics; iii. image guided surgery; iv. tissue engineering and tissue repair technology.

\section{Expansion of minimally invasive surgery and Natural Orifice Transluminal Endoscopic Surgery \\ procedures}

In the next 50 years, many instruments and technologies that are still in the developmental stage will come into use in clinical surgery and will be used to promote MIS. A good example of these technologies includes single port instruments such as the cobra, and others. It is obvious that in the near future many specialized surgical techniques will be developed for the use of single port MIS procedures. ${ }^{66}$

\section{Robotic surgery}

Robotic surgery may move into the field of remote robotic surgery, totally automated robotic surgery, and total robotic operating room with a robotic scrub nurse and a robotic circulating nurse. ${ }^{67}$ Surgical techniques in current use will probably be modified to use new instruments and technologies. However, the basic concept of surgical techniques will remain unchanged whether human beings perform the surgery themselves or whether they train robots to operate on their behalf.

Tissue engineering is becoming very popular. Today, artificial skin is being successfully produced for clinical use.$^{68,69}$ Scientists and clinicians are working together to produce artificial organs using stem cell technologies. They are also collaborating on the manipulation of cell function using special tissue culturing and nanotechnology. ${ }^{70}$ We are living in an age of organogenesis, and the current production of many artificial organs, such as the heart, intestine, liver and others, are evidence to the fact that the development of organogenesis will lead to their successful use in the very near future. ${ }^{71}$ In the near future, transplantation of artificial organs produced by organogenesis will become an important surgical procedure as replacement of diseased tissue/organs becomes more commonplace. Laser and plasma technology are also being used to repair damaged tissue and have achieved great clinical success. ${ }^{72,73}$ This type of tissue repair also requires special surgical techniques that will be developed parallel to the development of the technologies themselves.

Image-guided surgery will also become an important tool in the future. Further developments in technology, such as total body scans and instant imaging systems ${ }^{74}$ that show where the instruments are in relation to the surgical target and vital organs, will change the way we envisage topomatical anatomy and current surgical techniques. The development of image-guided surgery will also change the structure and administrative relationships between medical disciplines. In the near future, administration of the main medical departments such as surgery, medicine, pediatrics, obstetrics, gynecology, radiology, as well as divisions such as cardiology, cardiac surgery, gastroenterology and general surgery will be reorganized and these will re-emerge as cardiac science or gastroenterology science departments. For example, the cardiac science department will be made up of cardiac surgeons, cardiologists, cardiac anatomists, cardiac physiologists, cardiac radiologists, cardiac pathologists and others.

Non-invasive surgery will also be important in the near future. Cyber-knife technology, with the use of a robotic arm and delivery of radiation to a specific tumor site, is a revolutionary new idea which will extend the possibilities of non-invasive surgery. ${ }^{75}$ The cyber-knife is a frameless robotic radio surgery system invented by John Adler, a Stanford University 
Professor of Neurosurgery and Radiation Oncology, and Peter and Russell Schonberg of the Schonberg Research Corporation. ${ }^{76}$ The two main elements of the cyber-knives are the radiation produced from a small, leaner, practical accelerator and a robotic arm that allows the energy to be directed from any direction to any part of the body. In addition, non-invasive surgical tools using a femtosecond laser and confocal microscopy are used clinically for ophthalmology procedures. ${ }^{77}$ Many research projects are underway to further develop this technology for other parts of the body, such as brain tumors ${ }^{77} \mathrm{~A}$ femtosecond (FS) laser is one emits optical pulses with a duration well below one second ( $1 \mathrm{FS}=10$ at the power of $-15 \mathrm{~s}$ ). It belongs to the category of the ultra-fast laser or the ultra-short pulse laser.

\section{Distant future}

In the distant future, there will be a paradigm shift with the development of non-invasive surgical techniques in combination with nanotechnologies and a new era in the development of surgery, and subsequently in surgical techniques, will be opened.

Nanotechnology is an umbrella term for materials and devices that operate at the nanoskill ( 1 billionth of a meter). In terms of scale, a nanometer is approximately one $1 / 8000$ of a human hair or 10 times the diameter of a hydrogen atom. The size of the device can vary but starts from a ten thousand-logic element system that will occupy a cube of no more than one hundred nanometers. This is a volume slightly larger than 0.001 cubic microns. This would be sufficient to hold a small computer. For example, if red blood cells are approximately eight microns in diameter, the 100 nanomicroprocessor will be 80 times smaller than a red blood cell. Devices this size could easily fit into the circulatory system and could even conceivably enter individual cells.

The Nobel Prize winner for physics, Richard P. Feynman, was the first to mention the idea of nanotechnology. ${ }^{78}$ In his famous lecture, There is Plenty of Room at the Bottom (New York, 1950), he stated that ...the principles of physics, as far as I can see, do not speak against the possibility of maneuvering things, atom by atom.... However, his idea was not taken seriously and was certainly not implemented until 36 years later, in 1986, when Eric Drexler ${ }^{79}$ used the von Neumann architecture manufacturing system. He described his own manufacturing system for the production of nanotechnology devices. This system, known as Convergent Assembly, is capable of manufacturing raw materials from a nanometer to a meter in size in just 30 steps.

Nanotechnology in medicine ${ }^{80}$ and surgery ${ }^{81}$ will revolutionize surgical procedures and techniques changing the concept of diag- nostic and therapeutic modalities. Most surgical treatments as we know them today will be taken over by non-invasive nanosurgery within the next 25 years. The US National Science Foundation has predicted that the global market for nanotechnologies will reach one trillion or more within the next twenty years. ${ }^{82}$ The small and tiny nanorobot will have a very powerful navigation system and it will also have a range of sensors for rapid recognition and precise identification of target cells; if an antibody has two or three sites of sensitivity for attachment to a target cell, the nanorobot will have at least two to three sensitive sites to identify a target cell. It will have a powerful transport system and a storage system for the delivery of substances. It will also have a broadcasting system for communication with the outside. It will be manufactured from a flawless diamond for compatibility to the human body and it will have a long telescopic manipulator to hold on to the cell surface and start the manipulation on the cell surface or inside the cell. It will also have a central processing unit for computational purposes. With these kinds of properties and functions, the nanorobot will be able to perform many diagnostic and surgical treatment procedures in a non-invasive fashion. These diagnoses and treatment modalities will include the killing of cancer cells, the provision of oxygen to the tissue and the removal of carbon dioxide in cases of lung dysfunction, the provision of artificial cooling to the tissue, the ability to monitor the levels of different toxins and pharmaceutical compounds. Treatment modalities will also include among others taking snap shots of the entire system for diagnosis, cell repair and rejection, and drug delivery.

When it comes to surgical techniques, the era of nanotechnology will be one of cellular, subcellular and molecular surgery. For example, we can program nanoparticles to identify cancer cells at the site of origin of the tumor and destroy the cancerous cells by injecting radioactive materials or drugs into individual cells without damaging the healthy neighboring cells. Furthermore, nanoparticles will be able to target metastatic cells in remote sites in relation to the tumor of origin and destroy them wherever they are in the body. Nanotechnology will move invasive surgery from the organ level to non-invasive surgery at the cellular and subcellular levels. Dr. Nakamura developed a nanoneedle ${ }^{83}$ that operates on the cells. The needle is 200-300 nanometers in diameter and can be used to intervene on a single cell. It can penetrate the membrane of the cell and allow surgery to be carried out inside the cell on subcellular organelles. Dr. Nakamura developed the needle to manipulate embryonic stem cells. It could be used to control cell differentiation.
The purpose of this intracellular surgery would be to manipulate and control the proliferation of the embryonic stem cells into heart, kidney, liver or other cells. An experimental project with the nanoneedle on live human liver cells showed that an hour after the manipulation and nanosurgery, the human liver cells remained healthy ${ }^{84}$

It is obvious that, in the distant future, nanosurgery using nanorobotics will require entirely different surgical techniques for reaching target tissue, manipulating the tissue (or specific cells or subcellular organelles), and for repairing the tissue and completing surgical procedures. It is obvious that nanotechnology, like any other technology, will have its own flaws, hazards, safety issues and complications. This may also have a substantial effect and impact on the health of the world population. It may even open new ethical and legal issues for humanity that will need to be explored. These are not, however, within the scope of this paper. $^{85}$

In summary, surgical techniques have been used since the beginning of human evolution. Prehistoric evidence suggests that surgical techniques were used by primordial man to treat specific conditions. However, a lack of documentation means that we do not kow the extent to which surgical techniques were used. Different ancient civilizations have followed their own individual paths to develop surgical techniques with sufficient written documentation. Individually and collectively they have laid the foundation for the development of surgical techniques and have contributed to the development of surgery as a discipline. Modern, open surgical techniques flourished when the two key surgical barriers of pain and infection were removed. The current development of surgical technology provides an opportunity for new surgical techniques, such as MIS, NOTES procedures and others, to be developed. Further advances in existing surgical technology may create new ways in which surgical techniques such as MIS can be developed along with other novel technologies.

It is very difficult to predict future technological progress. Nevertheless, considering the emerging new revolutionary technologies, it is possible to predict that non-invasive surgical techniques with cellular and subcellular excision and repair of tissue will play a dominant role. With the full development of novel technologies it is obvious that within 50 to 100 years most of the elective non-urgent surgical procedures will be approached from a radically different perspective. However, some emergency procedures, particularly with regard to traumas, will be handled by open surgical techniques. Therefore, it can be concluded that surgical techniques began with trauma, existed for 9000 years, and will continue to exist into the future even if surgery as we know it 
will no longer exist, with the perfection of noninvasive medical treatment using novel pharmacological agents and advanced state-of-theart technologies.

\section{References}

1. Dictionary Merriam-Webster. Definition of "Surgery". http://dictionary.merriam-webster.com/dictionary/surgery Accessed: 0ctober 2011.

2. Wikipedia - The free Encyclopedia. Definition of "Surgery".http://en. wikipedia. org/wiki/Surgical_technique Accessed: 0ctober 2011

3. Dictionary Merriam-Webster. Definition of "Procedure". http://dictionary.merriamwebster.com/dictionary/procedure Accessed: October 2011.

4. Princeton University. Definition of "Procedure". http://wordnetweb.princeton. edu/perl/webwn Accessed: October 2011.

5. Dictionary.com. Definition of "Operation". http://dictionary.reference.com/browse/ope ration Accessed: October 2011

6. Dictionary Merriam-Webster. Definition of "Skill". http://www.merriam-webster.com/ dictionary/skill Accessed: October 2011.

7. Princeton University. Definition of "Skill". http://wordnetweb.princeton.edu/perl/web wn Accessed: October 2011.

8. Wikipedia - The free Encyclopedia. Definition of "Technique". http://en.wikipedia. org/wiki/Technique Accessed: October 2011.

9. Princeton University. Definition of "Technique". http://wordnetweb.princeton.edu/ perl/webwn Accessed: October 2011.

10. Agelarakis A. Early evidence of cranial surgical intervention in Abdera, Greece. A nexus to on head wounds of the Hippocratic corpus. Mediterranean Archaeol Archaeom 2006;6:5-18.

11. Weber J, Czarnetzki A. Trepanations from the early medieval period of southwestern Germany - indications, complications and outcome. ZBL Neurochir 2001;62:10-4.

12. Restak R. Fixing the brain, mysteries of the mind. Washington, DC: National Geographic Society; 2000. p. 256.

13. Bellwood P, Oxenham M. The expansions of farming societies and the role of the Neolithic demographic transition. In: Bocquet-Appel JP, Bar-Yosef 0 (eds). The Neolithic demographic transition and its consequences. Dordrecht: Springer; 2008. p. 13-34.

14. Ehrich RW (ed.). The Indus valley, Baluchistan and Helmand traditions. In: Neolithic through Bronze Age, chronologies in old world archaeology 2nd ed. Chicago, IL: University of Chicago Press;
1992. I:441-464, II:425-446.

15. Wright RP. The ancient Indus: urbanism, economy and society, case studies in early societies. Cambridge: Cambridge University Press; 2010.

16. Burridge AL. Ancient Egyptian medicine. JAMA 2003;290:826-7.

17. Brothwell DR. Digging up bones; the excavation, treatment and study of human skeletal remains. London: British Museum (Natural History); 1963. p. 126.

18. Kirkup J. Evolution of surgical instruments: an illustrated history from ancient time to the twentieth century. Novato, CA: US Library of Congress, Norman Surgery Series; no. 13; 2005. p. 517.

19. Ellis H. A history of surgery. Cambridge: Cambridge University Press, Medicine; 2001. p. 282.

20. Hammurabi (translated by Harper RF ). The Code of Hammurabi, King of Babylon (1700s BCE); 1904. http://en.wikisource. org/wiki/ Accessed: October 2011.

21. Rana RE, Arora BS. History of plastic surgery in India. J Postgrad Med 2002;48:76-8.

22. McDowell F. The source book of plastic surgery. Baltimore, MD: Williams and Wilkins Company; 1977. p. 65-85.

23. Bhishagratna KKL (ed.). Sushruta Samhita (An English translation of the Sushruta Samhita, based on original Sanskrit text, with a full and comprehensive introduction, translation of different readings, notes, comparative views, index, glossary and plates). Chapter 16. Calcutta; 1907. p. 152-154.

24. Graham AC. The date and composition of Liehtzyy. Asia Major 1960;8:139-98.

25. Sherer A, Epstein F, Constantini S. Hua Tuo, patron of surgeons, or how the surgeon lost his head! Surg Neurol 2004;61: 497-8.

26. Ellis H. Operations that made history. Cambridge: Cambridge University Press; 1996. p. 135.

27. Bishops WJ. The early history of surgery. New York, NY: Barnes \& Noble Publishing - Medical; 1996.

28. Hægerr K, Calnen R. The illustrated history of surgery. Chicago, IL: Fitzroy Dearborn Publishers - Medical; 1996.

29. Rutkow IM. Surgery - an illustrated history. St. Louis, M0: Mosby-Year Book Inc. in collaboration with Norman Pub.; 1996. p. 550 .

30. Galen. On the natural faculties. Books I, II, and III. Harvard: Loeb Classical Library; 2000.

31. Qayumi AK. Avicenna: A birth star from the east. J Invest Surg 1996;11:243-4.

32. Lyons AS, Petrucelli RJ. Medicine: an illustrated history. New York, NY: Harry N. Abrams, Inc. Publishers; 1996.

33. I.C.I.S.R., The First International Confe- rence on Iran and Silk Road. Cultural functions of halting place cities on the Silk Road: The case of Balkh in the Middle Ages. 12-14 Feb. 2011. http://en.iranandsilkroad.ir/?page_id=321 Accessed: 0ctober 2011

34. Smith RD. Avicenna and the canon of medicine: a millennial tribute. West J Med 1980;133:367-70.

35. Gordon D, Christensen L, Dayrit M, et al. Educating health professionals: the Avicenna project. Lancet 2008;371:966.

36. Ligon BL. Rhazes: his career and his writings. Semin Pediatr Infect Dis 2001;12: 266-72.

37. Abu Bakr Muhammad ibn Zakariya. [The book of medicine for Mansur.] http://www. nlm.nih.gov/hmd/arabic/E2_E4.html\#E2 Accessed: October 2011.

38. Sournia JC. The illustrated history of medicine. London: Harold Starke Publishers Ltd.; 1992. p. 584.

39. US National Library of Medicine, National Institutes of Health. Islamic culture and the medical arts: The Great Systematizers; April 1994. http://www.nlm.nih.gov/exhibition/islamic_medical/islamic_07.html Accessed: October 2011.

40. Spink MS, Lewis GL (eds). Abucasis surgery and instruments. Berkley and Los Angeles: University of California Press; 1973. p. 855 .

41. Encyclopedia Britannica. History of medicine: the development of the prevention and treatment of disease from prehistoric and ancient times to the 20th century (medicine and surgery before 1800). http://www.britannica.com/EBchecked/topi c/372460/history-of-medicine/35657/Thespread-of-new-learning? anchor=ref 412759 Accessed: October 2011.

42. Himmelman L. From barber to surgeon the process of professionalization. Sven Med Tidskr 2007;11:69-87. [Article in Swedish].

43. Ernst HC (translated by). Louis Pasteur: germ theory and its applications to medicine and surgery. In: Comptes rendus de l'Academie des Sciences, lxxxvi.; 1878. pp. 1037-43. http://www.pasteurbrewing.com/ articles/works-of-louis-pasteur-english/ louis-pasteur-germ-theory-and-its-applications-to-medicien-and-surgery.html Accessed: October 2011.

44. Qayumi AK, Patterson EJ. Basic surgical techniques: an illustrated manual. Vancouver, BC: Q\&Q Publishing; 2000.

45. Koch R. Die Ätiologie der MilzbrandKrankheit, begründet auf die Entwicklungsgeschichte des Bacillus anthracis [Investigations into Bacteria: V. The Etiology of Anthrax, Based on the Ontogenesis of Bacillus anthracis]. Cohns Beitrage zur Biologie der Pflanzen 1876,2:277-310. 
[Article in German].

46. Lister J. On the antiseptic principle in the practice of surgery. Br Med J 1867;2:24560.

47. Fenster JM. Ether day: the strange tale of America's greatest medical discovery and the haunted men who made it. New York, NY: Harper Collins; 2001.

48. Shklar G, Carranza FA. The historical background of periodontology. In: Newman MG Takei HH, Carrana FA, (eds): Carranza's clinical periodontology, 9th Ed. Philadelphia, PA: WB Saunders Company; 2002. p. 7.

49. Smith K. Raw Deal. New York, NY: Blast Books; 1998. p. 62-63.

50. Clemons BJ. The first modern operating room in America. Health, AORN Journal 2000. http://findarticles.com/p/articles/mi m0FSL/is_1_71/ai_59035023 Accessed: October 2011.

51. Porter R. The Cambridge illustrated history of medicine. Cambridge: Cambridge University Press; 2001. p. 376.

52. Time Magazine. US Science: transplanted head. January 17, 1955. Retrieved: 200712-16.

53. Demikhov VP. Experimental transplantation of vital organs. Authorized translation from Russian by Haigh B. New York, NY: Consultant's Bureau; 1962.

54. Shumacker HB. A surgeon to remember: notes about Vladimir Demikhov. Ann Thorac Surg 1994;58: 1196-8.

55. Cooper DKC. Vladimir Demikhov. Ann Thorac Surg 1995;59:1628.

56. Konstantinov IE. A mystery of Vladimir P. Demikhov: the 50th anniversary of the first intrathoracic transplantation. Ann Thorac Surg 1998; 5:1171-7.

57. Hatzinger M, Kwon ST, Langbein S, et al. Hans Christian Jacobaeus: inventor of human laparoscopy and thoracoscopy. J Endourol 2006;20: 848-50.

58. Clarke HC. Laparoscopy-new instruments for suturing and ligation. Fertil Steril 1972;23:274-7.

59. History of robotic surgery. http://biomed. brown.edu/Courses/BI108/BI108_2004_Gr oups/Group02/Group\%2002\%20Website/hi story_robotic.htm Accessed: October 2011.

60. Spinoff.nasa.gov. Robotic surgery. March 2, 2011. http://www.sti.nasa.gov/tto/spinoff2000/hm1.htm Accessed: October 2011.
61. Gerencher K, MarketWatch. Robots as surgical enablers - minimally invasive surgical techniques get boost from machine. February 3, 2005. http://www.marketwatch.com/story/a-fascinating-visit-to-ahigh-tech-operating-room?dist=msr_2 Accessed: October 2011.

62. Della Flora E, Wilson TG, Martin IJ, et al. A review of Natural Orifice Translumenal Endoscopic Surgery (NOTES) for intraabdominal surgery experimental models, techniques and applicability to the clinical setting. Ann Surg 2008;247:583-602.

63. Natural Orifice Surgery Consortium for Assessment and Research (NOSCAR ${ }^{\mathrm{TM}}$ ). 6th International Conference on Natural Orifice Translumenal Endoscopic Surgery (NOTES ${ }^{\mathrm{TM}}$ ) http://www.noscar.org/2011conference/ Accessed: October 2011.

64. ASGE, SAGES. ASGE/SAGES Working Group on Natural Orifice Translumenal Endoscopic Surgery White Paper October 2005. Gastrointest Endosc 2006;63:199203.

65. Satava R. The operating room of the future. From validation to implementation: how do we proceed? Medicine Meets Virtual Reality, MMVR 12, Newport Beach, CA, 15-16 Jan 2004

66. Satava RM. Advanced technologies and the future of medicine and surgery. Yonsei Med J 2008;49:873-8.

67. Lee KY, Mooney DJ. Hydrogels for tissue engineering. Chem Rev 2001;101(7):186979 .

68. Li S, Henry JD. Nonthrombogenic approaches to cardiovascular bioengineering. Ann Rev Biomed Eng 2011;13:451-75.

69. The Royal Society \& The Royal Academy of Engineering Report 2004. Nanoscience and nanotechnologies. Plymouth: Latimer Trend Ltd; 2004. p. 116.

70. Davies JA. Welcome to organogenesis. Organogenesis 2004;1: 1-2.

71. Leucht P, Lam K, Kim JB, et al. Accelerated bone repair after plasma laser corticotomies. Ann Surg 2007;246:140-50.

72. Stoffels E, Kieft IE, Sladek REJ, et al. Plasma needle for in vivo medical treatment: recent developments and perspectives. Plasma Sour Sci Technol 2006;15: S169-80.

73. U.S. Food and Drugs Administration.
Radiation emitting products. http://www. fda.gov/Radiation-EmittingProducts/ RadiationEmittingProductsandProcedures /MedicalImaging/MedicalX-Rays/ucm 115317.htm Accessed: October 2011.

74. Kilby W, Dooley JR, Kuduvalli G, et al. The CyberKnife ${ }^{\circledR}$ robotic radiosurgery system in 2010. Technol Cancer Res Treat 2010;9: 433-52.

75. Coste-Maniere E, Olender D, Kilby W, Schulz RA. Robotic whole body stereotactic radiosurgery: clinical advantages of the Cyberknife integrated system. Intl J Med Robot 2005;1:28-39.

76. Adler JR, Chang, SD, Murphy MJ, et al. The Cyberknife: a frameless robotic system for radiosurgery. Stereotact Funct Neurosurg 1997;69:124-8.

77. Hara W, Soltys SG, Gibbs IC. CyberKnife robotic radiosurgery system for tumor treatment. Expert Rev Anticancer Ther 2007;7:S1507-15.

78. Mehra J. Richard Phillips Feynman. 11 May 1918 - 15 February 1988. Biogr Mem Fellows R Soc 2002;48:97-128.

79. Drexler KE. Molecular machinery and manufacturing with applications to computation. MIT Archive Library, October 09 1991. http://e-drexler.com/d/09/00/Drexler MIT_dissertation.pdf Accessed: October 2011.

80. Freitas RA Jr. Nanomedicine, volume I: basic capabilities. Georgetown, TX: Landes Bioscience; 1999. http://www.nanomedicine.com/NMI.htm Accessed: October 2011.

81. Freitas RA Jr. Nanotechnology, nanomedicine and nanosurgery. Int J Surg 2005;3: 243-6.

82. Nano.gov, National Nanotechnology Initiative. http://www.nano.gov/ Accessed: 0ctober 2011.

83. Obataya I, Nakamura C, Han SW, et al. Nanoscale operation of a living cell using an atomic force microscope with a nanoneedle. Nano Letters 2005;5: 27-30.

84. AngioDynamics. NanoKinfe ${ }^{\circledR}$ system. http://www.angiodynamics.com/products/n anoknife Accessed: October 2011.

85. Edwards SA. The nanotech pioneers: where are they taking us? Weinheim: Wiley-VCH; 2006. p. 18. 